\title{
PAULO COELHO - A POSTMODERN AESOP
}

\section{AFSANA MOUSUME}

Assistant Professor, Department of English, Noakhali Science and Technology University, Chittagong, Bangladesh

The present study on 'Paulo Coelho - A Post-modern Aesop' is an attempt to assess prominent postmodern Brazilian writer Paulo Coelho as a writer and a keen observer of the human being who leads their life as the multifarious journey. To make the journey successful which ways should be followed and how personal self-be pacified and exacts its meaning are discussed in his texts which are selected for this study, where there is a relevance of his style with that of Aesop's style. Likewise, Aesop, Paulo Coelho speaks and guides in his writing as a representative of postmodern era showing pragmatic as well as spiritualistic attitude at a time. The research will focus on the works of Paulo Coelho where there are complex mixtures of tradition and modernity as well as mysticism and reality.
\end{abstract}

KEYWORDS: Postmodern Writing, Aesop's Fables, Spirituality \& Journey of Human Being

Received: Jun 12, 2018; Accepted: Jul 03, 2018; Published: Aug 28, 2018; Paper Id.: IJELOCT20181

\section{INTRODUCTION}

'Paulo Coelho - A Post-modern Aesop' is a study focusing/ considering mainly his text Like the Flowing River: Thoughts and Reflections; translated from the Portuguese by Margaret Jull Costa; published from Harper Collins Publisher. In support of this assessment on Paulo Coelho another text has taken as concern named Stories for Parents, Children and Grandchildren volume 1 and 2, which are anothers collections of his thoughts and reflections. The main focusing area Like the Flowing River: Thoughts and Reflections contains 102 short stories like thoughts and experiences of Coelho's himself and the rest of the texts are containing similarly 102 and 110 short stories respectively, whereas the Stories for Parents, Children, and Grandchildren, volume 1 and 2 firstly published in Coelho's own blog www.paulocoelhoblog.com. Interestingly enough, the way Coelho is telling the stories addressing no special character but the human being of all over the world is the same what the Greek slave Aesop told in his725 fables in the late to mid 6th century BC as Aesop's Fables. With didactic qualities, fables were initially told and transmitted in order to carry the appropriate lessons for living a life and to guide people toward being an upright man. (Tomasulo and Pawelski, 2012) and Aesop's fables have spread around the world as universal virtues and moral guidelines, and have invaded our vocabulary through phrases like "a wolf in sheep's clothing", "sour grapes", and "slow and steady wins the race". On the other hand, the thoughts and experiences which Coelho transformed into stories are like short fables, parables of modern life, bits of advice, and elaborations on the human condition through the sharing of his deep inner wisdom drawn from the many facts of everyday life which can be shared from generation to generation as a pathway to lead a meaningful life. Parable's traditional quality is to fascinate readers by its simple and easy to understand structural construction with keeping meaning inexplicable. This case can be compared with the Jesus in the Bible or the minstrels of the Middle Ages. Literary critic Idelber Avelar, professor for Latin American literature at Tulane University in New Orleans, judges Coelho's writing saying that he has used the pattern of the parable as a convincing component for modern commercial 
literature

So, the aim of this attempt is to mingle these two ideologies of different time and era and to show how despite being a post-modern, Paulo Coelho is champion to carry the Aesopian vision and mission of life via his jewel-like fables, packed with meaning on spirituality, life, ethics, and optimism in the utter meaninglessness.

To analyze this study, discussions focus on fables and Aesop's style, Coelho's technique of storytelling, his spiritualism as well as the existentialist ideology in the light of postmodern perspective.

Stories are one of the oldest ways we have of passing on knowledge, achieve wisdom, differentiate between good and evil. Fables, one of the finest designs of storytelling successfully serve these purposes and here Aesop's Fables are the strong and popular evidence of this sort of storytelling which started firstly by Phaedrus to translate the fables into Latin iambic trimeters, in the 1st century CE. The stories that we know today are probably based on the 3rd century CE Greek version by Babrius as copying of a copy. It seems that the first English translation appeared around the start of the 15th century. The main structure of an effective fable is carrying a moral lesson at the end of the story and the story is not lengthy enough.

Fables are a particular kind of stories with their individual structure and carrying a lesson to be learned. Aesop's Fables are not only carrying the lessons of goodness and badness or how the good is rewarded and bad is punished rather they are warning people through tales. There, animals are personifying and symbolizing human's flaws such as greed, arrogance, stupidity, timidity, naïveté, carelessness by which one can be deceived by another character, and help the deceiving character to fulfill his/her intention. In these cautionary tales the "good character" is shown as weak and the "bad character" is as strong, but ultimately this kind of portrayal gives the message that if thoughtful preventive actions are not properly measured power and evil can win over innocence and good (Clayton, 2008). If moral lessons are provided, it would be possible to follow the logical action to for championing the goodness. Again, fables reveal human attributes like kindness, empathy, intelligence, brevity through the unexpected situation as a result of the positive outcome. In a metaphorical way, if the moral is not clearly stated, fables contain some elements to understand the relationship of a character's making tricks or playing games, or what are the purposes for surprising others and doing harms, through which the reader can realize the outcome of the fable as fair and just consequences (Dorfman and Brewer, 1994). In Aesop's fables, animals play a role as protagonists as a component of 'human in disguise' so that readers can connect the reality of human experiences. (Sutton-Spence and Napoli, 2010, p. 442) For instance, Aesop's story of the fox and the crow is a story that involves the message of deception, the story of hare and tortoise carries the essence of the importance of time.

In this riveting collection of thoughts and stories, Paulo Coelho, the most prolific Brazilian novelist and lyricist and the author of the bestseller The Alchemist offers his personal thoughts and reflections on a wide range of subjects. The most of the Coelho's fictions are the depiction of the various journey in human life, and the considered texts of this study Like the Flowing River: Thoughts and Reflections and Stories for Parents, Children and Grandchildren volume Iand 2 are not actually fictions rather the realizations of the realities of real life. Coelho, here, offers an eye-opening realities of human life. Here, he selects no character or prefers no categorized events or incidents as a fictional element but uses the glimpses of magical words in the greatest, smallest or even simplest things of human life. 
To go through the Like the Flowing River is a pleasant walk with the stories of universal traditions and legends and joyful, amazing and dramatic real stories of human being's everyday life having a moralistic tone. It is the collection of Coelho's personal thoughts with some anecdotes, reflections, and tales from many cultures though wherever possible he has given the sources of the stories but most of them belong to the secret achievements of human heart and desire of the human soul. Similar to given moral lesson in Aesop's fables, these reflections carry moral messages in a very modern and postmodern way which are very clear at the end of each story through which Coelho shows us how life has lessons for us in every tough to trivial experiences of life.

Life seeks actions to make it successful as it is continuously involved in innumerable deeds by confronting various events and facing and receiving success and defeats, pioneering optimism, accepting the loss to assert the existence as the modern human being. Paulo Coelho's every text appears as a journey or as in quest of a way of life that enriches the meaning of existence. All through the considered texts of this study encircles the Coelhoian philosophy, his vision of life and mission to make it successful and meaningful. Being pragmatic and an existentialist he covers every nook and cranny of human life to reveal its meaning through his collections and experiences. But the interesting matter is, though he was raised in a Catholic family he left his faith in his 20s; however, he later returned to it and became a devout Catholic, and here in his thoughts and reflections a proof is found regarding his spiritual attitude and asserting himself as a transcendentalist.

Paulo Coelho starts his Like the Flowing River: Thoughts and Reflections with a preface where he justifies himself for his choice to be a writer going beyond the decisions and choices of his parents. As it is the collection of his personal thoughts, he pointed eight points in support of his selection to convince his family and to execute his free will as an individual; and this sort of justification and his purpose of writing carry the essence of the verses "Be like the flowing river" of Manuel Bandeira that he used as a requiem.

To serve his purpose all through the stories and articles Coelho uses metaphors, images, symbols where necessary. If it starts with the story 'The Story of the Pencil' where a boy was making conversation with his grandmother and she was explaining in reply of his asking that how a mere pencil can show him the path to happiness. The grandmother mentions five qualities of the pencil which give us lessons to find out our inner self.

"I have to stop writing and use a sharpener. That makes the pencil suffer a little, but afterward, he's much sharper. So you, too, must learn to bear certain pains and sorrows, because they will make you a better person." (it's a quote from the text, p 10). She is trying to impart information onto him about life, “...it always leaves a mark. In just the same way, you should know that everything you do in life will leave a mark, so try to be conscious of that in your every action." to assert the existence as the human being. 'How to Climb Mountains' is not just a story rather a Coelhoian methodology or an encouraging technique to reach one's own goal successfully. Here, he suggests eleven steps with separate title by which reader can realize the essence of struggle to live a life, but nature is always there to refuel human's life and teaches one to be self-appreciative, promising and exemplary for others so that they can be hopeful to face the adverse reality but ultimately receive success by revealing the secret to materialize their dreams. The story of 'Ghengis Khan and the Falcon' that teaches about the folly of anger - and the art of friendship. 'The Dead Man Wore Pyjamas' is another gem among the collection, where the horrible reality of loneliness and meaninglessness of human life are projected.

"Then I thought about the dead man in pyjamas about his complete and utter isolation, to the point that, for twenty years, no one in the whole world had noticed that he had simply vanished without a trace. I can only conclude that worse 
than hunger or thirst, worse than being unemployed, unhappy in love or defeated and in despair, far worse than any or all of those things is feeling that no one, absolutely no one, cares about us." (p 39, another quote from the text)Again, what happens in 'Where the Monkey puts his Hand' the same thing happens in our own lives.

"The need to have a particular thing - often something small and useless - ends up making us prisoners of that need." This story is true because when we like something and believe that we need it, it becomes an obsession, we start ignoring all its bad sides and we can't feel satisfied until we get it, and this is the usual nature of human being. 'The importance of the cat in meditation' makes us feel that in our everyday life how many things are done unnecessarily leaving them with absurd meaning. This story is about the monastery of Mayu Kagi which teaches the Zen Buddhism. An old master used to bring his cat during meditation in order to enjoy its company. When he died, the monastery continued to allow the cat to attend the classes. Generation after generation, people started believing that the cat is primordial to meditation and developed theses about that. This custom stopped when an allergic master decided to remove the cat from his daily practices.

"But it took two hundred years for everything to return to normal, and all because, during that time, no one thought to ask why the cat was there."

Totally agreed with the author, it can be said that many of the customs and traditions we believe in today are only a heritage of our parents and grandparents and we don't even know why we keep doing them. This phenomenon becomes more dangerous when these traditions are related to Religion. Indeed, the social, economic and political conditions in a country can influence people and make them use religion to invent new rituals which have actually no relation to religion. The prayer that I forgot' is a story about the author himself. When he visited Sao Paulo, he discovered a prayer he'd read in the early eighties and that he totally forgot. While praying he addressed God as Lord seeking His protection of his humanly desire. It teaches to be proactive and do what we think we should do to help humanity and to maintain a legacy after our death. Even more fascinating are Coelho's thoughts on dreams and death. In 'The Music Coming from the Chapel' Coelho shows the way of praying to soothe our mind and soul even though it is a simple thing because the omnipotent resides everywhere no matter whether great or small. In 'My Funeral' and 'Living Your Own legend' he alerts us of the fixed and ultimate reality, that is Death and advises us not to be afraid of something that is inevitable and uncontrollable despite the fear that comes hand in hand with our sense of morality. Rather we should utilize this fear as our motivation and a way out to pursue the dreams we kept aside for this unchanged reality. He reminds us to dream no matter how big, no matter how absurd. In his stories, a Manuel series are there, where we find the character Manuel in three different stages of his life. Here, Manuel is the symbolic representation of the postmodern human being who starts his life from nothingness and gradually turns his life to keep pace with the situation. In this story Manuel portrays the real postmodern Coelho figure which is assessed by the author himself, “...despite never having given a meaning to his life, he was capable of loving, of providing for his family, and of doing his work in a dignified manner. Meanwhile, even though his life had a happy ending, his last days on earth were very complicated." This is the story where we come across the author's postmodern attitude with an Aesopian voice at the end of the story saying, "The optimist and the pessimist both die in the end, but each lives his life in a completely different way." It indicates that every human being carries both optimistic and pessimistic attitudes simultaneously but these two separately operate and reflect in the life and define the meaning of life. Another postmodern attitude is received in the story titled 'Destroying and Rebuilding'. While visiting the site of a Zen Buddhist temple in Guncan-Gima, in reply of author's asking the man in charge replied saying, “...nothing in this life is eternal and that even 
temples are in need of constant improvement." Apparently, it reflects the practicality of living a life which meets constant changing and improvement, but at the same time it bears the moral tone that enchants nothing is fix in human life, everything requires nourishment for getting a better result. One of the different articles in this collection is 'Statutes for the New Millennium' where Coelho states directly his own sixteen rules considering postmodern nature of human being. Each rule itself carries the post-modernistic attitude at the same time headed to mysticism, like as, "Each human being was given two qualities: power and the gift, power directs us towards our destiny; the gift obliges us to share with others what is best in us."(p114, another quote from the text). But these rules turn into paradoxical when he says at the $16^{\text {th }}$, "All statues to the contrary are revoked" which indicates the postmodern irrational attitude of human being. The story "Self Deception" is another proof of postmodern human attitude in the guise of an animal's voice. In this story Coelho starts with his moral lesson at the very beginning of the story showing how human beings are very quick and harsh to apply their judgemental attitude, saying, “...always to find an excuse for our own misdeeds, or to blame someone else for our mistakes."

The article 'Thank you, President Bush' in this collection was the most widely published and much-viewed article about the war before the invasion of Iraq by America. Here, the author criticised the unworthy, illogical and whimsical decision that the then American government took against Iraq. This is actually the cruel proof of postmodern era that is the Coelho's cup of tea.

The story 'The Way of the Bow' starts with Paulo's philosophy "An action is a thought made manifest." which reminds us of the old moral saying 'practice makes a man perfect'. This story also teaches us how to control our self by using words, behaving with others because these acts are like bows, while thrown can never get back.

From the above discussion on the stories from Like the Flowing Rivers: Thoughts and Reflections, it is noticed that how postmodern attitudes of the author are at the end connected with the author's spiritual attitudes. Not only in this text, we see the author's same nature in his another text Stories for Parents, Children and Grandchildren volume 1 and 2 , where the story titled 'A Story by Kahlil Gibran' we experience the real scenario of the present competitive world where our children are merely the victim of their parents or superiors to fulfil their unfinished and long cherished desire. We never give someone a scope to be what he/she wants to be rather set others as an example to be followed to be such. This is the crude and irrational reality for $21^{\text {st }}$-century children. Like this story, some other stories entitled 'The Sorrowing Father' and 'The Sorrowing Mother' carries the similar essence that is the guardian's regrets about children. 'Thinking about Death', 'How to achieve Immortality', 'After Death', 'A Death Foretold', 'Heaven and Hell' are carrying author's philosophy of life and death. And the stories 'Krishna will hear your prayer', 'The Essence of Forgiveness', 'Where God lives', 'The importance of Prayer', 'How to please the Lord', 'Another Name', 'The Monk and the Prostitute', 'How to see the All in everything', 'The Divine Melody' are the stories from both the volume carry the author's spiritual view and some other carries the author's philosophy of love and hope.

Through his stories, articles, thoughts, and observations Coelho tries to convey his philosophy of life concerning postmodern human nature and to assert their existence. Though regarding postmodernism existentialism resides far away back but it is the all-time related idea to establish a human identity as an individual. Existentialism deals with the human conditions and their problems in this world. Jean-Paul Sartre philosophizes, in comparison with others only man is real andhis existence is superior to others. He claims that there is no existence of supernatural powers and God, and man's actions and free will are only responsible for his own life. As a moralistic theory, Existentialism states, freedom and responsibility are interlinked and the freedom of human beings will be exacted by their actions. 
As a visionary, Coelho's shows us how the whole universe acts as leader and supports us while we are in need of achieving something in our life. As Coelho concerns mostly on the way and art of living in his writing, he suggests, like an existentialist, how we can make life more attractive and meaningful since all things in this world are interrelated. To Coelho, life is a journey with dreams and desires and we should accept this journey with love and patience so that we can reach our goal because we know nothing about what is coming next or what is going to happen in our future. (Soni, 2014)

Jean-Paul Sartre, as a pioneer of Existentialism, developed the idea that the actions of a human being shape his/her life. Existentialism asserts man is not only responsible for his own deeds rather he is also responsible for others' actions, so s/he has to be conscious to make life meaningful as well as to take the responsibility of life in this universe. (Sartre, 1965)

As a firm believer in the power of love, according to Coelho, love is the only force which has the power to change the world. He writes that those who love to conquer the world and have no fear of loss. Who takes the path of love always suffers but in every love there lies the seed of growth. The more we love, the closer we come to spiritual experience and our souls are truly enlightened and illuminated by the love and can experience 'madness of saintliness'. True love is an act of total surrender.

Coelho's novels assert the most important law- changing your vision and thinking would change the world around you. He makes the reader see the hidden and unseen stratum of visions and thoughts. His book The Fifth Mountain too speaks about the faith conspicuously. In By the River Piedra I Sat Down and Wept Coelho has given a voice of his philosophy:

“There are many ways to serve our Lord. If that's your destiny, go in search of it. Only a man who is happy can create happiness in others." (104)

As this paper concentrates on Paulo's postmodern writing with the blend of Aesopian attitude it is found that he covers almost all the qualities of postmodern writing. The postmodern literary writers frequently select their subjects and components of writing like characters, historical evidence, religious events, and beliefs, and language and structural pattern not only from their surroundings or their own country but also include diversity throughout the world to make it international. Likewise, Paulo chooses people as characters to convey his message or solution from prostitutes to priest, common man to the king, children to superior and so on. He as a supporter of multiculturalism covers the values from Buddhism, Hinduism, Zionism, Christianity, and Islam to bear the real delight of reading. He nicely applies abstract and concrete symbols which represent various disciplines like history, geography, theology, philosophy, psychology, mythology, science and arts. He is not following logic or science as modernists do rather he prioritizes his senses, emotion and willpower. The author uses 'Pastiche' from the various works of previous writers and religious books including the Bible, the Holy Quran, the Bhagabat Gita. In some relevant cases, metafiction is found in his stories in the form of allegories, quotations and allusions that fulfill his Aesopian structural form. Like Aesop, he selects his language as simple and prefers everyday vocabulary so that the narrative style stays more close to the reader, and meaning and message of the story can easily be understood by every person as well. It seems that Aesop to whom his way of storytelling is compared belongs to ancient time and stays in different perspective which is far more away from modern man's crisis; apparently it is received by almost all people that in Aesop's fables animals are characterizing human beings showing their follies and negativities and at the end good wins over bad, that may contradict Paulo's postmodern writing caring the moral lessons. 
Here lies no doubt in Paulo's writing and giving morals in comparison with Aesop because Paulo here addresses human beings who are in crisis with their own follies and adversities and it is human being who can change their situation through their positive actions, practices and nourishing values to make their life meaningful by which even the world and time can be changed. He in all his stories carries a moral not entirely related to religious but the way of thinking to hear one's own heart and Soul. Coelho's philosophy is voiced that everything happening in one's life is one's own responsibility and the result of one's own deeds like the Aesop's moral 'As you sow, so shall you reap'. The outlook of Life is reflected in his stories. He shows how the good aims, dreams, thoughts, and lastly the actions bring positive result and ultimately connect to the Soul of the world. He shows how the power of love acts and achieves earthly happiness and then to the happiness of the afterworld.

Coelho's religious explorations, ranging from mysticism to monotheism, are well received in the Western world. Once he left Catholicism but later on it seems he takes shelter on Supreme power, God. The common denominator with all these stories is that the author tries to mix up Religion with Superstition or Fun, which makes the story become shocking and lose its credibility. I think that stories shouldn't be imaginary when we talk about God, prophets, saints or real people in general. Imaginary stories should contain imaginary characters. Moreover, we should be more careful when we deal with Religion for fear of crossing the red lines or being disrespectful to religious Dogmas. The traditional religious practices are important. They allow us to share with others the communal experience of adoration and prayer but we must not forget that spiritual experience is above all a practical experience and the spiritual path can only be traveled through the daily experience of love.

\section{CONCLUSIONS}

Coelho through his life experiences had internally come to terms with the fact that everyone must live out his or her madness. A little bit of madness is quite healthful. In one of his interviews with Marika Schaerti he says:

If madness means being other than "normal" that is fine with me. If it is threatening for oneself and society, there is a problem. My motto is: A little bit of madness is quite healthful.

Paulo Coelho is an excellent storyteller, inspiring people all over the world to see beyond the ordinary and into the remarkable. He wants to pass on his views about how we receive spiritual guidance or wisdom. His perspective involves talking about both the mind and the heart. The Times rightly observes, 'His books have had a life-enhancing impact on millions of people'. Paulo Coelho is a storyteller with the power to inspire nations and to change people's lives and can be called 'Post-modern Aesop.

\section{REFERENCES}

1. Clayton, E. (2008). Aesop, Aristotle, and animals: the role of fables in human life. Humanitas 21, 179-200.

2. Dorfman, M., and Brewer, W. (1994). Understanding the points of fables. Discourse Process. 17, 105-129.

3. Coelho, Paulo, Like The Flowing River: Thoughts and Reflections,(2006). trans. Margerate Jull Costa. India: Harper Collins Publishers

4. By the River Piedra I sat down and wept. (2005) Trans. Alan r. Clarke New Delhi: Harper Collins Publishers

5. Stories for Parents, Children and Grandchildren. (2007). www.paulocoelhoblog.com 
6. Soni S (2014) Life Realized through Riddles: A Study of Paulo Coelho's The Alchemist Journal of English Language \& Literature 1: 85-91.

7. Sartre (1965) The Philosophy of Existentialism In W Baskin JEAN PAUL SARTRE Essays in Existentialism CANADA: THE CITADEL PRESS Secaucus New Jersey, pp: 36-38.

8. Sodian, B., Taylor, C., Harris, P., and Perner, J.(1991). Early deception and the child's theory of mind: false trails and genuine markers. Child Dev. 62, 468-483. doi: 10.2307/1131124.

9. Sutton-Spence, R.. and Napoli, D. J.(2010). Anthropomorphism in sign languages :a look at poetry and storytelling with a focus on British sign language. Sign Lang. Stud. 10, 442-475,504.doi:10.1353/sls.0. 0055

10. Gautam, D., \& Jhajharia, P. (2016). The Effect of Workplace Spirituality on Employee's Self-Empowerment.

11. Tehrani, J. J. (2013). The phylogeny of little redridinghood. PLo SONE 8:e78871. doi:10.1371/journal.pone.0078871

12. Tomasulo, D. J., and Pawelski, J. O.(2012). Happily ever after: the use of stories to promote positive interventions. Psychology 3, 1189-1195.doi: 10.4236/psych.2012.312A176

13. More, Vijay R.(2015). Paulo Coelho's Philosophical Vision as Reflected in His Novels. The South Asian Academic Research Chronicle. ISSN 2454-1109 Vol 2.7, 15-21

14. Khoso, Muhammad Hasan, Abdul Hameed Panhwar, and Sanaullah Ansari. (2016). An exploration of the literary stylistic analytical techniques of postmodernism in Paulo Coelho's novel: The Alchemist. An International Research Journal of Language and Literature. 119 - 132 http://sujo.usindh.edu.pk/index.php/ 